\title{
ОСОБЛИВОСТІ АСОРТИМЕНТУ ЮВЕЛІРНИХ ВИРОБІВ РЕЛІГІЙНОГО ЗМІСТУ
}

\author{
О.И. ПЕРЕДРИЙ, И.С. СТАСЮК \\ Луикий национальный технический университет \\ ОСОБЕННОСТИ АССОРТИМЕНТА ЮВЕЛИРНЫХ ИЗДЕЛИЙ \\ РЕЛИГИОЗНОГО ЗНАЧЕНИЯ
}

\begin{abstract}
O.PEREDRIY, I.STASIYK
Lutsk national technical university

FEATURES OF THE ASSORTMENT OF JEWELRY RELIGIOUS VALUES

https://doi.org/10.36910/6775-2310-5283-2018-11-13

Мета. Метою даного дослідження $\epsilon$ аналіз асортименту ювелірних виробів релігійного змісту, визначення їх особливостей і характерних товарознавчих ознак.

Методика. При дослідженнях використовували методи системного аналізу, абстрагування і групування.

Результати. Досліджено асортимент ювелірних виробів релігійного змісту та фактори, що впливають на його формування, визначено основні особливості релігійних виробів, подано їх класифікацію за різними ознаками.

Наукова новизна. Визначено характерні ознаки ювелірних виробів релігійного змісту та проаналізовано вплив даних характеристик на формування асортименту релігійних виробів.

Практична значимість. Зростання попиту на ювелірні виробів релігійного змісту спричинюе необхідність аналізу даного сегменту ринку ювелірних виробів, визначення найважливіших факторів впливу на асортимент даної групи товарів, а глибокий зміст релігійних символів зумовлює необхідність детального вивчення їх характерних ознак $i$ особливостей.
\end{abstract}

Ключові слова: ювелірні вироби релігійного змісту, асортимент, канон, символ.

Постановка проблеми у загальному вигляді і її зв'язок з важливими науковими та практичними завданнями. Культові прикраси - особлива товарна категорія. У сучасному ювелірному виробництві ця група стоїть дещо окремо, хоча при виготовленні релігійних виробів ювеліри використовують сучасні техніки, модні напрямки ювелірного мистецтва. Кожний релігійний виріб має свою задумку, богословську концепцію, втілену у художніх формах та образах, це не просто товар, а смисловий, а іноді і мистецький, витвір.

Питання оцінки якості ювелірних виробів висвітлюється в працях багатьох вчених та практиків. Найбільший вклад у розвиток та становлення $\longrightarrow(117$ 
товарознавства і експертизи коштовностей зробили М.M. Назимок, T.М. Артюх [1], О.К. Шликов, В.В. Індутний, В.І. Татаринцев, В.І. Павлишин, В.В. Татаринцева та ін. У своїх працях вони розглядали питання, пов'язані 3 методологією, термінологією, ціноутворенням та експертизою ювелірних виробів. Насьогодні розроблено та апробовано багато методик оцінювання ювелірних виробів 3 дорогоцінних металів. Перспективами подальших досліджень у цьому напрямі $\epsilon$ комплексне оцінювання споживних властивостей ювелірних виробів, розробка методик оцінювання виробів різних груп за призначенням, зокрема і ювелірних виробів релігійного змісту. Попит на дану групу ювелірних прикрас в останні роки постійно зростає, асортимент розширюється, а покупці більш вимогливо відносяться як до якості виробів в цілому, так і до їх відповідності релігійним канонам, здатності задовільняти духовні потреби.

Об 'єкт дослідження: ювелірні виробив релігійного змісту.

Цілі статmі: визначити товарознавчі особливості ювелірних виробів релігійного змісту.

Виклад основного матеріалу дослідження. Достовірних статистичних даних, які розкривали б обсяги виробництва і продажу ювелірних виробів релігійної тематики, сьогодні немає. Однак можна сміливо стверджувати, що зростання цього сегменту ринку ювелірних виробів значне. Збільшується кількість спеціалізованих ювелірних майстерень, що спеціалізуються на виробництві виробів релігійного призначення. Великі ювелірні підприємства щороку оновлюють свої колекції релігійної тематики, розширюють їх асортимент від декількох різновидів натільних хрестів до широкого асортименту ювелірних виробів церковного призначення. Такий інтенсивний ріст був би неможливий без зростаючого попиту з боку населення [2].

Найбільшим попитом на ринку користуються вироби середньої цінової категорії - до 250-300 грн. Вони відрізняються простотою у виконанні. Для вірян, які шукають більш складного виконання релігійного виробу, підходить категорія з вищою ціною. При цьому виробники впевнені, що в майбутньому питання ціни на цю категорію ювелірних товарів відійде на другий план. У міру зростання освіченості в питаннях православ'я та інших релігій покупців буде більше цікавити саме символічна складова виробів. Заглиблюючись в духовний бік, споживач приходить до розуміння самого феномена релігійного виробу, символьного та духовного значення, які вкладені в різних формах.

Як наслідок, варто очікувати розширення асортименту виробів: зосередження на різноманітності традиційних форм, пошук нових. Справжні 
майстри православного ювелірного мистецтва прекрасно розбираються в православній символіці та органічно поєднують священні знаки і символи в своїх роботах [3].

Культові прикраси - особлива товарна категорія. Кожний релігійний ний виріб має свою задумку, богословську концепцію, втілену у художніх формах та образах. Усі вони мають зовнішні особливості у вигляді символів, написів, які тим чи іншим способом виявляють приналежність виробу до певної релігії. Це робиться невипадково, і віруючі завжди звертають на це увагу. Саме тому, окрім номінальної вартості та художньо-естетичної цінності, культові прикраси мають ще духовне значення. У сучасному ювелірному виробництві ця група стоїть дещо окремо, хоча при виготовленні релігійних виробів ювеліри використовують сучасні техніки, модні напрямки ювелірного мистецтва [4].

Ювелірні вироби релігійного змісту класифікують за такими ознаками:

- за релігійною приналежністю;

- за призначенням;

- за видом матеріалу;

- за оздобленням;

- за видами.

За релігійною приналежність усі вироби можна поділити на такі групи:

- православна тематика;

- ісламська тематика;

- іудаїка;

- слов'янська тематика;

- тематика інших релігій.

Ювелірні вироби релігійного змісту за призначенням поділяються на такі підгрупи:

- особисті прикраси: натільні хрести, іконки, перстні, каблучки, браслети, підвіски, сережки;

- інтер'єрні вироби: лампади, панагії та хрести, об’ємно-пластичні композиції;

- ікони: вінчальні, домашні, для автомобілів та ін.;

- вироби, що мають змістовну тематику різних віросповідань.

Особисті прикраси. Сьогодні на вибір для православних віруючих представлені різноманітні види натільних хрестів, які продаються у ювелірних магазинах, церквах, монастирях та православних крамницях. Православна та католицька церкви не встановлюють строго канону для натільних хрестиків. 
Хоча, звичайно, віряни та досвідчені майстри 3 першого погляду відрізнять православний хрестик від католицького. Основна вимога до сакрального символу православної віри - форма і символіка натільного хреста повинна відповідати православним традиціям. Сьогодні існує велике розмаїття форм православного хреста. Причому церква визнає не тільки восьмикутний хрест (як традиційний), але і шестикінечний, i чотирикутний, i з Розп'яттям, i без розп'яття, і взагалі без будь-якого зображення. Нанесені на хрест символи вказують на певні аспекти християнського віросповідання. $€$ прості чотириконечні натільні хрести, є ускладнені символічною формою, доповнені образами святих, а $є$ і виготовлені у вигляді мощовиків, тобто мініатюрних скриньок із стулками, які щільно закриваються.

Окрім хрестів, ювелірна промисловість випускає безліч різноманітних підвісок та кулонів у вигляді невеликих нагрудних іконок, або, як їх називають, образків. На них зображуються прославлені чудесами ікони Христа, Божої Матері та шанованих святих.

При виборі підвісок варто враховувати, на якому ланцюжку вони будуть носитись, плетення ланцюжка повинно гармоніювати з композицією ладанки чи образка.

Іудеї та мусульмани часто носить таку прикрасу як хамса, або поіншому «долоня Давида». Образ долоні вказує на знак захисту. Ці вироби часто багато прикрашені каміння і орнаментом. Хамсу також прикрашає такі символи як Зірка Давида і Очі Давида. Також ці знаки виготовляють як окремі прикраси з золота і срібла.

Серед ювелірних релігійних виробів мусульман переважають підвіски у вигляді напівмісяця та зірки, зображення ісламських святинь, підвіски 3 написами релігійного змісту.

Основна частка продажів виробів релігійного змісту в останні роки припала на натільні іконки та срібні перстні. Серед перстнів зросла кількість вінчальних парних з написами релігійного змісту, оформлені з використанням релігійних символів. Стабільною популярністю користуються невеликі «захисні» перстні 3 одним написом «Спаси і збережи» та досить масивні перстні-печатки, на яких на площі виробу наноситься зображення святого чи знаки релігійного змісту (хризма, риба, монограма). Значно зріс продаж браслетів з срібними пластинами, на які нанесені слова молитов, класичні іконографічні мотиви.

Також варто відмітити зростання попиту на підвіски та бусини для набірних браслетів, на які нанесені культові знаки як православної релігії, так 
i інших релігій світу. Вони відрізняються надзвичайно великою різноманітністю як за матеріалом, так і формою: дзвіночки, риби, ангелочки, постаті святих, хризми, хамса та ін.

Відомі фірми виробники ювелірних виробів за останній рік значно розширили свої колекції релігійної тематики за рахунок випуску виробів нових форм - ладанки, мощовики, слова-обереги. Класичний натільний мощовик - це пустотілий виріб, що відкривається (як мініатюрна шкатулка) для зберігання святинь. Мощовик призначений для зберігання та постійного ношення біля себе певних сімейних святинь, якими можуть виступати частинки мощів святих, ладан або жменька із Святої Землі.

Складні мають дещо іншу форму: це механічно (переважно шарнірно) з'єднані декілька мініатюрних іконок, які складаються та розгортаються як книжка. Усі різновиди релігійних ємностей насичені класичними іконографічними мотивами, на них наносяться слова-обереги, молитви, зображені святі.

Постійними стабільним попитом користуються вироби для проведення обрядів хрещення - срібні ложечки та гребінці, які хоч і не мають релігійного змісту, але асоціюються у споживачів з певними обрядами. На окремі з них наносяться монограми з іменем святих, в честь якого названо дитину, знаки релігійного змісту.

Варто відмітити появу на ринку ювелірних виробів запонок та зажимів для галстуків, на які наносяться релігійні символи. Проте попит на такі вроби невисокий.

В буддизмі, ісламі та інших релігіях дуже популярні вервиці. Вони потрібні для рахунку прочитаних молитов. Являють собою шнурок або стрічку, на яку нанизані намистини, які виготовляються 3 дорогих порід дерева, дорогоцінних каменів, мінералів, плодів та насіння рослин.

Інтер'єрні вироби. Оригінальністю архітектоніки формотворення вирізняються лампади, де завдяки унікальному способу конструювання основного каркаса композиції вогонь, що передбачений за функціональним призначенням, незважаючи на погодні умови, практично не згасає. Окремі виробники, зокрема, ювелірний концерн «Лобортас» випускає кабінетні лампади, які є взірцем ювелірного мистецтва.

Також до інтер'єрних виробів релігійної тематики відносять настільні хрести, набори для бюро, підставки для книжок, підсвічники, мінори. В останні роки особливої популярності набули подарункові пасхальні яйця, виконанні з використанням давніх ювелірних технік. 
Ікони. Особливу та найбільшу групу серед ювелірних виробів релігійного призначення займають ікони. Ікони поділяються на групи за призначенням:

- домашні: настінні та настільні;

- $\quad$ автомобільні;

- іконостасні.

Усі вони відрізняються за розмірними параметрами, видом матеріалу та оздобленням. Найпопулярнішими насьогодні є срібні та золоті ікони, виконані методом чеканки. Також користуються сталим попитом вироби, в яких сучасний метод виготовлення - шовкографія - поєднується з традиційним золочінням або срібленням. Деякі ікони виготовляють на дерев'яних підкладах. В таких випадках, як правило, використовують цінні породи деревини.

Окрему групу складають сувеніри релігійної тематики. Церковні православні сувеніри відносяться до особливої категорії подарунків, які можна піднести близькій і рідній людині просто без приводу або ж з нагоди великого свята, наприклад, Різдва або Пасхи, вінчання чи хрестин дитини. Також такий подарунок можна подарувати на день народження, день ангела. Для віруючої людини це дуже цінний подарунок, який у важкі хвилини життя допоможе зібрати всі сили, прийняти негаразди і йти далі зі смиренням в душі. До цієї групи відносять нагрудні знаки, ювілейні монети, пасхальні яйця, прикраси для паски, очисники води, кружки для свяченої води, набори для хрещення. Усі вони витримані в єдиному стилі з дотриманням релігійної тематики. Як правило, ця група виробів виготовляється зі срібла.

Висновки. Виріб релігійного змісту, якщо його носити 3 метою задоволення саме духовних потреб, повинен в повній мірі відповідати чітко встановленим правилам (канонам) тієї чи іншої релігії. релігійні символи товар непростий, з глибоким змістом. Кінцевим споживачем таких виробів можуть бути від воцерковлених віруючих до таких, що практично не знайомі 3 церковними правилами та канонами і використовують релігійні символи в якості модних прикрас. Хоча віряни більшою мірою знайомі з товаром і самої традицією релігійних символів, але навіть їм часто необхідно роз'яснювати символізм, який закладений художником у виробах. Це вимагає спеціальних знань від продавців, що збільшує вимоги при прийомі на роботу, і потенційно ускладнює процес роботи для магазину. При продажу таких виробів, необхідно, розбиратися хоча б в основах віри. Звичайно не треба забувати що магазин це не церква, але у відділах продажів культових виробів доцільно 
мати спеціальну літературу. Компаніям, що спеціалізуються на виготовленні виробів релігійного призначення, варто супроводжувати свою продукцію пояснювальною інформацією.

\section{Література:}

1. Артюх Т.М. Проблеми безпечності та якості ювелірних виробів [текст] / Т.М. Артюх, І. В. Григоренко // Товари і ринки. - 2008. - №. 1. - С.131-138.

2. Вартанян В.М. Дослідження розвитку українського ринку ювелірної продукції [текст] / Вартанян В.М. // Економіка та управління підприємствами машинобудівної галузі: проблеми теорії та практики. - 2015. - № 3. - С. 108-117.

3. Православні символи. Кращі колекції [електронний ресурс] // Режим доступу: https://simvol.com.ua/

4. Передрій О.I. Особливості формування асортименту ювелірних виробів релігійного змісту [текст] / O.I. Передрій // Актуальні проблеми теорії і практики експертизи товарів: матеріали III міжнар. наук.-практ. інтернет-конф. (м. Полтава, ПУЕТ, 16-18 березня 2016 р.) / ПУЕТ. - Полтава : ПУЕТ, 2016. - С. 104-106/

5. Стасюк I. Огляд асортименту ювелірних виробів релігійного змісту [текст] / I. Стасюк, О. Передрій // Якість та безпечність товарів : матеріали міжнарод. наук.-практ. конф. молодих вчених та студентів, (м. Луцьк, 25 березня 2017 р.) / М-во освіти та науки України, Луцький НТУ. - Луцьк : ред.-вид. відділ Луцького НТУ, 2017. - С. 123-124.

Purpose. The purpose of this article is the analysis of religious jewellery assortment and determination of its peculiarities and special features.

Methodology. The methods of system analysis, abstraction and grouping were used in the research.

Results. The research of the religious jewellery assortment was carried out. The factors that influence the assortment of jewellery with religious meaning were determined. The main peculiarities of religious jewellery and its classification are shown.

Originality. The main features of jewellery with religious meaning are determined and their influence on the formation of religious jewellery assortment is shown.

Practical value. The increasing demand for religious jewellery causes the necessity of the analysis of this part of Ukrainian jewellery market, while the deep meaning of religious symbols is the reason of the great importance of studying the peculiarities and special features of religious jewellery.

Key words: jewellery with religious meaning, assortment, canon, symbol.

Цель. Целью данного исследования является анализ ассортимента ювелирных изделий религиозного содержания, определение их особенностей и характерных товароведных признаков.

Методика. При исследованиях использовали методы системного анализа, абстрагирования и группировки. 
Результаты. Проанализировано ассортимент ювелирных изделий религиозного содержания и факторы, влияющие на его формирование, определены основные особенности религиозных изделий, представлена их классификация по различным признакам.

Научная новизна. Определены характерные особенности ювелирных изделий религиозного содержания и проанализировано влияние данных характеристик на формирование ассортимента религиозных изделий.

Практическая значимость. Рост спроса на ювелирные изделия религиозного содержания вызывает необходимость анализа данного сегмента рынка ювелирных изделий, определения важнейших факторов влияния на ассортимент данной группь товаров, а глубокий смысл религиозных символов является причиной необходимости детального изучения характерных особенностей религиозных изделий.

Ключевые слова: ювелирные изделия религиозного содержания, ассортимент, канон, символ.

Рекомендовано до публікаиії докт.техн.наук, професором Луиького НТУ Байдаковою Л.І. Дата надходження в редакиію 22.01.2018 p. 